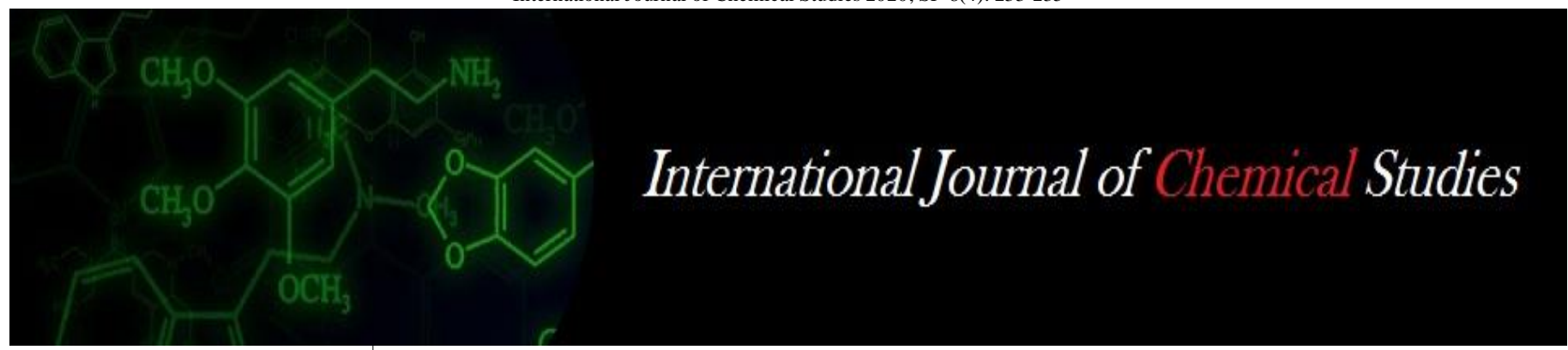

P-ISSN: 2349-8528

E-ISSN: 2321-4902

www.chemijournal.com

IJCS 2020; SP-8(4): 233-235

(C) 2020 IJCS

Received: 14-05-2020

Accepted: 16-06-2020

Amarnatha N

Department of Sericulture,

College of Agriculture

University of Agricultural

Sciences, GKVK, Bengaluru,

Karnataka, India

Chandrashekhar S

Department of Sericulture,

College of Agriculture

University of Agricultural

Sciences, GKVK, Bengaluru,

Karnataka, India

Narayanaswamy TK

Department of Sericulture,

College of Agriculture

University of Agricultural

Sciences, GKVK, Bengaluru,

Karnataka, India

Srikanth GA

Department of Sericulture,

College of Agriculture

University of Agricultural

Sciences, GKV K, Bengaluru,

Karnataka, India
Corresponding Author: Chandrashekhar S Department of Sericulture, College of Agriculture University of Agricultural Sciences, GKVK, Bengaluru, Karnataka, India

\section{Organics in mulberry (Morus spp.) on egg traits of seed cocoon silkworm (Bombyx mori L.) races}

\author{
Amarnatha N, Chandrashekhar S, Narayanaswamy TK and Srikanth GA
}

DOI: https://doi.org/10.22271/chemi.2020.v8.i4d.9979

\begin{abstract}
The mulberry varieties Viz., $\mathrm{S}_{36}$ and $\mathrm{M}_{5}$ grown with the application of different organics to supplement nitrogen yielded good response with respect to egg technological traits of PM and $\mathrm{CSR}_{2}$ seed cocoon races with the application of Biofertilizers @ $10 \mathrm{~kg} / \mathrm{ha}$ each of Azospirillum brasilense + Aspergillus awamori +20 per cent recommended nitrogen each through compost, vermicompost, green manure, castor oil cake and 20 per cent $\mathrm{N}$ and recommended dose of $\mathrm{P}$ and $\mathrm{K}$ through inorganic fertilizers $\left(\mathrm{T}_{4}\right)$ recorded significantly higher rate of moth emergence $(92.13$ and $88.50 \%)$,high female moth weight $(0.730$ and $0.955 \mathrm{~g}$.),high male moth weight $(0.469$ and $0.597 \mathrm{~g}$.),more ovaries weight $(0.209$ and $0.325 \mathrm{~g}$.), high fecundity (466.24 and 506.44 eggs/ laying) and highest hatching percentage (95.31 and 94.93\%). However, the next best treatment was $\mathrm{T}_{5}(20$ tonnes FYM/ha/year + 300: 120: $120 \mathrm{NPK} \mathrm{kg} / \mathrm{ha} / \mathrm{year}$ through chemical fertilizers) recorded rate of moth emergence( 91.0 and $87.50 \%)$, female moth weight $(0.706$ and $0.910 \mathrm{~g}$.), male moth weight $(0.451$ and $0.564 \mathrm{~g}$.$) , ovaries weight (0.202$ and $0.310 \mathrm{~g}$.), fecundity (459.15 and 501.64 eggs/ laying) and hatching percentage ( 94.35 and $93.98 \%)$ respectively in $\mathrm{PM}$ and $\mathrm{CSR}_{2}$ seed cocoon races.
\end{abstract}

Keywords: Mulberry, silkworm, moth, fecundity, hatchability

\section{Introduction}

The mulberry is the sole source of nourishment from which silkworm derive nearly 70 per cent of the silk protein (Fried, 1958) ${ }^{[3]}$. According to Miyashita (1986) ${ }^{[4]}$ among several factors responsible for successful cocoon crop, the mulberry leaf and silkworm seed accounts to the extent of $38.20 \%$ and $3.10 \%$, respectively. It is therefore clear that mulberry leaf plays a dominant role in cocoon production as source of nutrition to the silkworm. Hence, the quality of leaf act as a buffer and helps in getting successful cocoon crop. Quality of leaf helps to stabilize the cocoon crop success.

The silk scenario in the country has reached tremendous strides to bring qualitative changes in production. Though overall development of sericulture during the past four decades brings sharp focus on the positive aspect of increasing quality of silk production, yet in recent days due to globalization and free trade wherein, markets especially the expert ones are becoming more and more competitive consciousness on the quality aspects are momentum. Therefore, both qualitative and quantitative aspects are to be focused for improving the silk industry.

Among the numerous factors that influence the productivity in sericulture, silkmoth seed is of prime importance. As it is known that, the quality silkmoth seed is the backbone of sericulture industry, which plays a decisive role in the success of commercial cocoon crop. Thus, silk industry sustains on the strength of silk moth seed quality, crop performance and productivity at basic seed forms and seed areas. The timely supply of required quantity of quality of disease free layings (dfls) to the sericulturists is one of the responsibilities for achieving stable cocoon production.

One of the major factors responsible for yield gap in sericulture is the nutritional status of mulberry leaf. It is well known that the silkworm, Bombyx mori L. It is typical monophagous insect feeding only on mulberry (Morus spp.).It derives all the essential nutrients from the mulberry leaf for its growth and development. The silkworm is a kind of very efficient bioreactor for protein synthesis just like yeast in fermentation industry. Therefore, the nutrition of the silkworm is of due importance not only for the maintenance of its life but also for both seed and silk production. 
To enhance and sustain the productivity, INM practices are the key issues which have been developed in various agricultural crops. Similarly, even in mulberry cultivation, a need for adoption of more ecofriendly techniques is being felt. The increased use of organic manures, farm yard manure, biofertilizers, vermin and bio-compost, recycling seri-farm waste etc., to replace chemical fertilizers, will not only balance the soil health but also induce mechanism of revitalizing it. However, imbalanced use of NPK fertilizers, especially excessive use of nitrogen and insufficient to nonusage of potassium fertilizersis the most common practice among the farmers. The application of organic manures to the fields has become limited due to many reasons apart from non- availability.
Keeping these aspects in view a study on role of organic based nitrogen management through application of different organic manures in mulberry and its impact on egg technological traits of seed cocoon silkworm (Bombyx mori L.) races were studied.

\section{Materials and Methods}

A field experiment was taken up in irrigated mulberry garden at Main Research Station, Hebbal, UAS, Bengaluru.The mulberry varieties viz., $\mathrm{S}_{36}$ and $\mathrm{M}_{5}$ grown with $60 \times 60 \mathrm{~cm}$ spacing. The experiment was laid out in a Randomized complete block design (RCBD) with six treatments and three replications each. The mulberry cultivation practices were followed as per Dandin et al. (2010) ${ }^{[2]}$. The treatment details are as follows.

Table 1: The treatment details

$\mathbf{T}_{1}: 50$ per cent recommended $\mathrm{N}$ through castor oil cake +50 per cent recommended $\mathrm{N}$ and recommended dose of $\mathrm{P}$ and $\mathrm{K}$ through inorganic fertilizers $\mathbf{T}_{2}: 50$ per cent recommended $\mathrm{N}$ through vermicompost +50 per cent recommended $\mathrm{N}$ and recommended dose of $\mathrm{P}$ and $\mathrm{K}$ through inorganic fertilizers

T. Biofertilizers @ $10 \mathrm{~kg} / \mathrm{ha}$ each of Azospirillum brasilense + Aspergillus awamori +25 per cent recommended $\mathrm{N}$ each through compost, green

$\mathbf{T}_{3}$ : manure (Glyricidia maculate), castor oil cake, vermicompost with recommended dose of $\mathrm{P}$ and $\mathrm{K}$ through inorganic fertilizers

T. Biofertilizers @ $10 \mathrm{~kg} / \mathrm{ha}$ each of Azospirillum brasilense + Aspergillus awamori + 20 per cent recommended nitrogen each through compost,

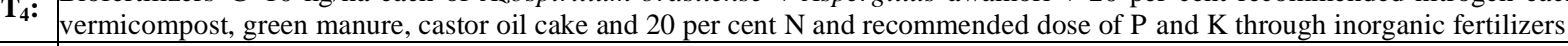

$\mathbf{T}_{5}: 20$ tonnes FYM/ha/year + 300: 120: $120 \mathrm{NPK} \mathrm{kg} / \mathrm{ha} /$ year through chemical fertilizers (control) Only chemical fertilizers applied @ 300: 120: 120 NPK kg/ha/year

Recommended $\mathrm{P}$ and $\mathrm{K}$ fertilizers were applied in the form of single super phosphate and Muriate of potash respectively. Organic manures and fertilizers were applied by ring and basin method at a distance of $15 \mathrm{~cm}$ from the base of each plant of both $\mathrm{S}_{36}$ and $\mathrm{M}_{5}$ mulberry varieties. After 35

$\mathbf{T}_{6}$. days of pruning the $\mathrm{S}_{36}$ (for young age silkworm) and $\mathrm{M}_{5}$ mulberry (for late age worms) leaves raised through different kinds of organics were used for rearing the pure breeds Viz., PM and $\mathrm{CSR}_{2}$.The 36 hybrid combinations were prepared by utilizing the pure silkworm races which were reared on mulberry grown with the application of above said combination of organic and inorganic fertilizers. Then, the hybrid silkworms were reared on mulberry leaf grown with the application of recommended package of practice (Dandin et al., 2010) ${ }^{[2]}$. The data was analyzed statistically by using simple CRD and two way factorial CRD as outlined by Cochran and Cox (2000) ${ }^{[1]}$.

\section{Results and Discussion}

The observations on seed cocoon silkworm races viz., PM and $\mathrm{CSR}_{2}$ as influenced by different organics in mulberry are presented in Tables 1\&2.The egg technological traits of seed cocoon races such as rate of moth emergence, female and male moth weight, ovaries fresh weight, fecundity and hatchability differed significantly in both $\mathrm{PM}$ and $\mathrm{CSR}_{2}$, when fed on mulberry raised through INM.

Table 2: Silk moth egg traits of pure races as influenced by feeding silkworm with mulberry leaf grown with different organics

\begin{tabular}{|c|c|c|c|c|c|c|c|c|c|c|}
\hline \multirow{2}{*}{ Treatments } & \multicolumn{2}{|c|}{ Rate of moth emergence (\%) } & \multicolumn{2}{|c|}{ Female moth weight } & \multicolumn{4}{|c|}{ Male moth weight $(\mathrm{g})$ Ovaries (fresh weight) (g } & \multicolumn{2}{|c|}{ Fecundity (eggs/moth) } \\
\hline & $\mathbf{P M}$ & CSR2 & PM & CSR2 & PM & CSR2 & PM & CSR2 & PM & CSR2 \\
\hline $\mathrm{T}_{1}$ & $88.44(70.12)$ & $84.75(66.99)$ & 0.623 & 0.822 & 0.389 & 0.499 & 0.192 & 0.279 & 449.68 & 487.86 \\
\hline $\mathrm{T}_{2}$ & $89.36(70.96)$ & $85.50(67.60)$ & 0.637 & 0.853 & 0.399 & 0.523 & 0.196 & 0.290 & 454.01 & 493.88 \\
\hline $\mathrm{T}_{3}$ & $90.28(71.84)$ & $86.50(68.43)$ & 0.655 & 0.877 & 0.413 & 0.541 & 0.199 & 0.299 & 456.35 & 496.40 \\
\hline $\mathrm{T}_{4}$ & $92.13(73.72)$ & $88.50(70.17)$ & 0.730 & 0.955 & 0.469 & 0.597 & 0.209 & 0.325 & 466.24 & 506.44 \\
\hline $\mathrm{T}_{5}$ & $91.20(72.76)$ & $87.50(69.28)$ & 0.706 & 0.910 & 0.451 & 0.564 & 0.202 & 0.310 & 459.15 & 501.64 \\
\hline $\mathrm{T}_{6}$ & $87.52(69.31)$ & $84.38(66.70)$ & 0.605 & 0.813 & 0.375 & 0.493 & 0.188 & 0.276 & 445.89 & 484.59 \\
\hline F test & $*$ & $*$ & $*$ & $*$ & $*$ & $*$ & NS & $*$ & $*$ & $*$ \\
\hline S.Em \pm & 0.700 & 0.546 & 0.002 & 0.006 & 0.001 & 0.004 & 0.001 & 0.002 & 3.17 & 3.87 \\
\hline C.D. at $5 \%$ & 2.097 & 1.634 & 0.006 & 0.017 & 0.004 & 0.012 & 0.003 & 0.006 & 9.49 & 11.60 \\
\hline
\end{tabular}

*: Significant at $5 \%$ NS: Non-significant

Figures in the parentheses are angular transformed values

Table 3: Silk moth egg traits of pure races as influenced by feeding silkworm with mulberry leaf grown with different organics

\begin{tabular}{|c|c|c|c|c|c|c|}
\hline \multirow{2}{*}{ Treatments } & \multicolumn{2}{|c|}{ Egg weight (g/1000 eggs) } & \multicolumn{2}{|c|}{ Specific gravity } & \multicolumn{2}{|c|}{ Hatchability (\%) } \\
\hline & PM & CSR2 & PM & CSR2 & $\mathbf{P M}$ & CSR2 \\
\hline $\mathrm{T}_{1}$ & 0.452 & 0.486 & 1.022 & 1.040 & $92.45(74.02)$ & $92.08(73.63)$ \\
\hline $\mathrm{T}_{2}$ & 0.452 & 0.489 & 1.023 & 1.040 & $93.40(75.09)$ & $93.03(74.67)$ \\
\hline $\mathrm{T}_{3}$ & 0.453 & 0.489 & 1.023 & 1.041 & $94.11(75.93)$ & $93.74(75.49)$ \\
\hline $\mathrm{T}_{4}$ & 0.454 & 0.491 & 1.025 & 1.041 & $95.31(77.46)$ & $94.93(76.97)$ \\
\hline $\mathrm{T}_{5}$ & 0.453 & 0.490 & 1.024 & 1.041 & $94.35(76.23)$ & $93.98(75.78)$ \\
\hline $\mathrm{T}_{6}$ & 0.451 & 0.485 & 1.022 & 1.040 & $91.97(73.51)$ & $91.61(73.14)$ \\
\hline F test & NS & NS & NS & NS & $*$ & $*$ \\
\hline S.Em \pm & - & - & - & - & 0.107 & 0.246 \\
\hline C.D. at $5 \%$ & - & - & - & - & 0.322 & 0.737 \\
\hline
\end{tabular}

*: Significant at $5 \%$ NS: Non-significant

Figures in the parentheses are angular transformed values 
The rate of moth emergence (92.13 and $88.50 \%)$, weight of male $(0.469$ and $0,597 \mathrm{~g})$ and female $(0.730$ and $0.955 \mathrm{~g})$ moths, weight of ovaries (0.209 and $0.325 \mathrm{~g})$, fecundity (466.24 and 506.44) and hatching percentage (95.31 and 94.93\%) respectively in $\mathrm{PM}$ and $\mathrm{CSR}_{2}$ seed cocoon races was found to be significantly higher with mulberry leaf feeding obtained through the application of Biofertilizers @ $10 \mathrm{~kg} / \mathrm{ha}$ each of Azospirillum brasilense + Aspergillus awamori +20 per cent recommended nitrogen each through compost, vermicompost, green manure, castor oil cake and 20 per cent $\mathrm{N}$ and recommended dose of $\mathrm{P}$ and $\mathrm{K}$ through inorganic fertilizers $\left(\mathrm{T}_{4}\right)$.

Though non significant differences were exhibited with respect of egg weight and specific gravity in both PM and $\mathrm{CSR}_{2}$, the highest egg weight $(0.454$ and $0.491 \mathrm{~g} / 1000)$ and specific gravity (1.025 and 1.041) was observed, when they were reared on mulberry leaves raised with the application of Biofertilizers @ $10 \mathrm{~kg} / \mathrm{ha}$ each of Azospirillum brasilense + Aspergillus awamori + 20 per cent recommended nitrogen each through compost, vermicompost, green manure, castor oil cake and 20 per cent $\mathrm{N}$ and recommended dose of $\mathrm{P}$ and $\mathrm{K}$ through inorganic fertilizers $\left(\mathrm{T}_{4}\right)$.

The rate of moth emergence, weight of male and female moths, weight of ovaries, fecundity and hatching percentage was high in $\mathrm{PM}$ and $\mathrm{CSR}_{2}$, which might be due to good quality leaves harvested from conjunctive application of biofertilizers, different organic manures along with fertilizers. Improvement in grainage parameters could be due to the fact that, other than nitrogen, these organic sources provide elements like $\mathrm{Ca}$ and $\mathrm{S}$ needed for the synthesis of sulphur containing amino acids like cystine and methionine, which might be required for synthesis of chorion or egg shell development. Ca may also helps in strengthening of the egg shell.

Scanning of available literature revealed that no such similar type of work was carried out previously with regard to influence of different organics on seed technological traits of seed cocoon races. Hence, comparisons were not made. However, the literature on hybrid silkworm races revealed that, significantly maximum rate of moth emergence, fecundity and hatchability was noticed in $\mathrm{CSR}_{2} \mathrm{XCSR}_{4}$ hybrid reared on the leaves obtained through the application of 50 per cent $\mathrm{N}$ through castor cake +50 per cent $\mathrm{N}$ through urea (Ravikumar et al., 2005) ${ }^{[5]}$.

\section{Conclusion}

Based on the study it can be inferred that, the mulberry leaves produced with the application of different organic manures to supply major nutrient ' $\mathrm{N}$ ' can supplement the nutritional requirements of seed cocoon silkworm races by virtue of producing nutritionally balanced mulberry leaf. Thus organic based nitrogen management in mulberry would help to generate good quality seed cocoons for the production of quality commercial silk moth dfls would benefit hybrid silk moth egg producers due to the availability of quality seed cocoons.

\section{Acknowledgement}

The authors greatly acknowledge the financial assistance provided through DST funded project entitled" Significance of organically grown mulberry on biochemical and reproductive biology of silkworm seed cocoons (Bombyx mori L.)" from DST, New Delhi and Department of Sericulture, UAS,GKVK, Bengaluru for providing facilities to conduct research.

\section{References}

1. Cochron, Cox. Experimental Design-Procedures for the Behavioural Sciences, Cole Publishing Company, 2000, 319-380.

2. Dandin SB, Jayaswal J, Giridhar K. Handbook of sericulture technologies, Central Silk Board, India, 2010, 55-60.

3. Fried WG. Nutritional requirements of phytophagous insects. Ann. Rev. Entomol. 1958; 3:57-74.

4. Miyashita Y. A report on mulberry cultivation and training methods suitable for bivoltine rearing in Karnataka, 1986, 1-7.

5. Ravikumar A, Narayanaswamy TK, Krishnappa A, Bhaskar RN. Impact of varied groups of organics at different levels supplied to mulberry on pupal and egg traits of silkworm. Progress of Research in Organic Sericulture and Seri- Byproducts Utilization, 2005, 148158. 